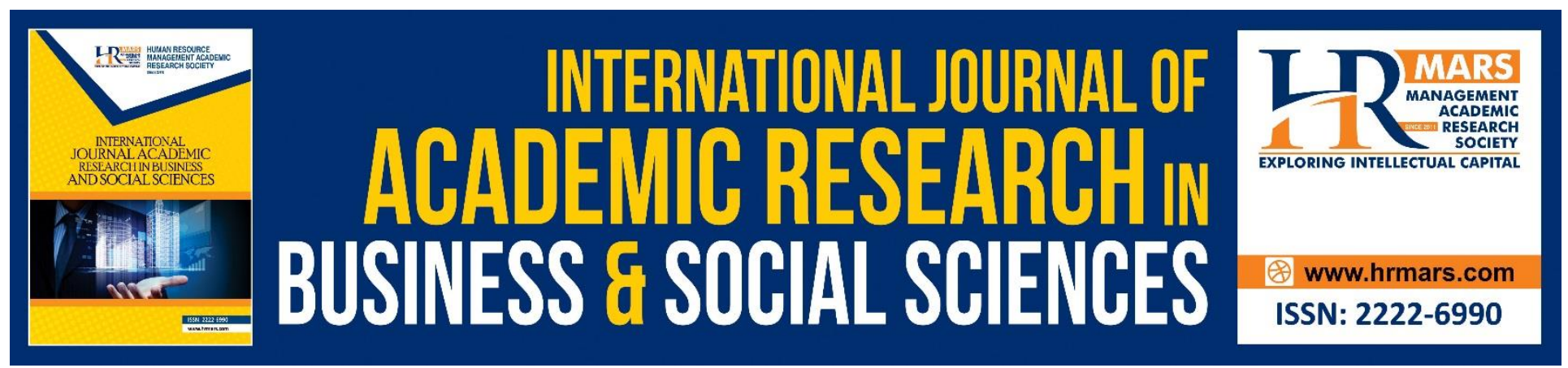

\title{
Individual Factors Influence on Consumer Complaint Behavior: The Case of Millennial
}

\author{
Azmi Mat, Ainunnazlee Mohd Ali, Norliza Saiful Bahry, Nur Liana Kori \& \\ Zarina Abdu Munir
}

To Link this Article: http://dx.doi.org/10.6007/IJARBSS/v8-i11/5283

DOI: $10.6007 /$ IJARBSS/v8-i11/5283

Received: 11 Nov 2018, Revised: 01 Dec 2018, Accepted: 09 Dec 2018

Published Online: 14 Dec 2018

In-Text Citation: (Mat, Ali, Bahry, Kori, \& Kori, 2018)

To Cite this Article: Mat, A., Ali, A. M., Bahry, N. S., Kori, N. L., \& Kori, N. L. (2018). Individual Factors Influence on Consumer Complaint Behavior: The Case of Millennial. International Journal of Academic Research in Business and Social Sciences, 8(11), 1603-1612.

\section{Copyright: (C) 2018 The Author(s)}

Published by Human Resource Management Academic Research Society (www.hrmars.com)

This article is published under the Creative Commons Attribution (CC BY 4.0) license. Anyone may reproduce, distribute, translate and create derivative works of this article (for both commercial and non-commercial purposes), subject to full attribution to the original publication and authors. The full terms of this license may be seen

at: http://creativecommons.org/licences/by/4.0/legalcode

\section{Vol. 8, No. 11, 2018, Pg. 1603 - 1612}

Full Terms \& Conditions of access and use can be found at http://hrmars.com/index.php/pages/detail/publication-ethics 


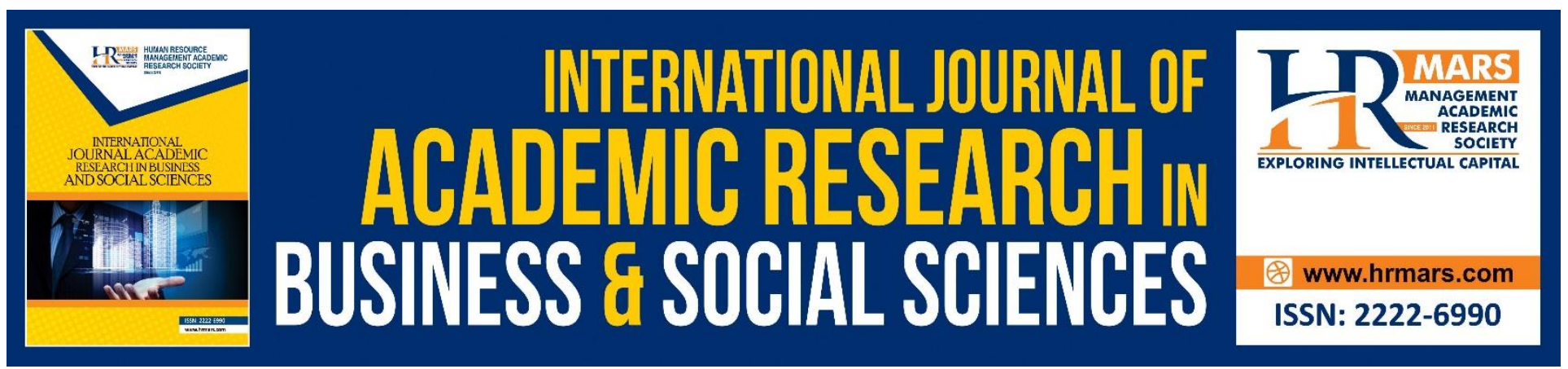

\title{
Individual Factors Influence on Consumer Complaint Behavior: The Case of Millennial
}

\author{
Azmi Mat, Ainunnazlee Mohd Ali, Norliza Saiful Bahry, Nur Liana \\ Kori \& Zarina Abdu Munir \\ Faculty of Business \& Management, Universiti Teknologi MARA Selangor, 42300 Bandar Puncak \\ Alam Selangor \\ Email: azmimat@uitm.edu.my
}

\begin{abstract}
Understanding Consumer Complaint Behavior (CCB) is important in present competitive business environment as it serves as quality improvement tools in enhancing customer experience. However, studies on consumer complaint behavior that been conducted in Malaysia are relatively few. Complaint should not been viewed as a problem. Consumers today are better educated, more sophisticated, more demanding and are willing to pay for services that meet or exceed their expectations. The purpose of this study is to examine the relationship between attitude, knowledge, personality and CCB among Millennial. A survey was conducted that involved 400 customers who experienced dissatisfaction of car vehicle repair services. The finding of this study indicates that only attitude and knowledge were statistically significant to CCB. Consumer satisfaction or dissatisfaction ratings are good indicators of firm's performance to forecast future profit and return on investment. Therefore service managers should continuously and increasingly use customer satisfaction index as criterion for analyzing service performance to create more loyal customers.
\end{abstract}

Keywords: Complaint behavior, Millennial, Customer satisfaction

\section{INTRODUCTION}

The era during which consumers took everything that was offered by the marketers is now gone. Nowadays, consumers are better educated. They are unwilling to compromise quality (Huang et. al., 1996), and use various means to voice the opinions that may make or break business. Consumers today, especially the young workers, are demanding for the value of their monies. They are not hesitant to complaint if they are not satisfied with the good or services provided, or the response of the seller in relation to their purchase; they are using the social media to express anger and frustration. 
In current scenario, customers not only lodge their complaint via offline methods, they might lodge a complaint or express their dissatisfaction on social media. This is because, the main frustration for complaining is the poor communication level that customer may encounters with the company. A common problem appears to be that service providers choose no to answer emails or respond to phone calls, which leaves customer in poor position in terms of obtaining redress. The numbers of consumers are using the Internet and social media to communicate their complaint are dramatically increased, especially among Millennial (Clark, 2013). The Millennial generations presents both opportunities and challenge to marketers. Due to their familiarity and heavy usage of technology and social media, Millennials seems to be on group of consumers who, when dissatisfied with a product or service experience or the improper handling complaint, may retaliate on the Internet. Therefore, the company would not be able to address the complaints directly, yet it will impact their organization reputation and sales profit. Millennial generations are those individuals born after 1980 who come of the age 35 and below. On the other hand, the attitude of this Millennial, are the ones giving high impact to this evolution of social media by interacting using a new level of platforms such as Facebook, Twitter and Instagram. It is estimated that this generation makes up to $49.3 \%$ in year 2010 of adult population who made complaints on social media. On top of that, in year 2014, the Millennial that influence this evolution increased to $62.95 \%$ of adult population. These statistics are evidence that Facebook and Twitter provide a perfect platform for dissatisfied Millennial to expose their anger towards organization.

\section{LITERATURE REVIEW}

Consumer complaint behavior began to generate attention from researcher in marketing research fields during the 1970's. Most of the studies of the CCB have been conducted in industrialized western countries where consumerism activity is accepted phenomenon (Kaynak et al., 1992). In addition, most studies on CCB were conducted in the United States during the 1970's and 1980's (Hunt, 1977). To date, only few studies concerning complaint behavior have been undertaken in South-East Asia. The first study conducted by Keng et al., (1995) attempts to profile complaint behavior of Singaporean and followed by study that carried out by Phau and Sari (2004) which attempts to investigate why some people tend to complaint while other do not, among Indonesian consumers. In 2017, Christina et al., conducted a study to examine Generation Y's positive and negative word of mouth in social media and mobile technology. However, very few study be conducted to investigate CCB among millennial. Thus, this study is conducted to investigate further about the CCB, especially among millennial.

\section{METHODLOGY}

A survey was conducted to a total of 400 customers who experienced dissatisfaction of car vehicle repair services. Respondents were given a screening question before they can participate in this study. Only those respondents who have experienced a dissatisfaction episode and seek redress directly or complaint to the third party will be selected to participate in this study. Besides, only respondents who aged below than 35 years old were chosen to provide their response. The seven items measurement of attitude and nine items of personality were adapted from Keng at al., (1995). The seven items of knowledge also have been adapted from Zhoa and Md Nor Othman (2010) and 
INTERNATIONAL JOURNAL OF ACADEMIC RESEARCH IN BUSINESS AND SOCIAL SCIENCES

Vol. 8, No. 11, Nov, 2018, E-ISSN: 2222-6990 @ 2018 HRMARS

ten items of complaint behavior adapted from Alfansi and Atmaja (2011) and Ekiz and Au (2009). All the items tested were measured based on five Likert Scales. In further data analysis, partial least square has been used to analyze the causal relationship between attitude, knowledge, personality and CCB.

\section{RESULT}

\section{Measurement Model}

In a measurement model, the analysis aims to identify the construct validity that estimates the loading factors. According to Hair, Black, Babin and Anderson (2010), a measurement model that can be fit when the cut-off value of factor loading are 0.05 . From table 1, there were two items of knowledge (item 1 and item 2) and two items of consumer complaint behavior (item 5 and item 6) have been deleted in this model due to lower factor loading. Thus the factor loading of this study has a loading greater than 0.05 and this can interpret that the higher loading confirms the construct validity.

Further analysis was conducted convergent validity, which estimates the composite reliability and average variance extracted. After deleted items, the finding indicates that the composite values and average variances extracted values of attitude ( $C R=0.916, A V E=0.611)$, personality ( $C R=0.0892$, $A V E=0.504)$, knowledge $(C R=0.869, A V E=0.764)$ and $C C B(C R=0.835, A V E-0.508)$ were greater than 0.5 and 0.7 as recommended by Hair et al., 2010. 
INTERNATIONAL JOURNAL OF ACADEMIC RESEARCH IN BUSINESS AND SOCIAL SCIENCES

Vol. 8, No. 11, Nov, 2018, E-ISSN: 2222-6990 @ 2018 HRMARS

Table 1: Convergent Validity

\begin{tabular}{|c|c|c|c|c|}
\hline Constructs & Items & Item Loading & $\begin{array}{c}\text { Composite } \\
\text { Reliability (CR) }\end{array}$ & $\begin{array}{c}\text { Average Variance } \\
\text { Extracted (AVE) }\end{array}$ \\
\hline \multirow[t]{7}{*}{ Attitude } & C1_A & 0.836 & 0.916 & 0.611 \\
\hline & C2_A & 0.771 & & \\
\hline & C3_A & 0.734 & & \\
\hline & C4_A & 0.841 & & \\
\hline & C5_A & 0.819 & & \\
\hline & C6_A & 0.713 & & \\
\hline & C7_A & 0.746 & & \\
\hline \multirow[t]{9}{*}{ Personality } & C1_P & 0.83 & 0.892 & 0.504 \\
\hline & $\mathrm{C} 2 \mathrm{P}$ & 0.712 & & \\
\hline & C3_P & 0.75 & & \\
\hline & C4_P & 0.816 & & \\
\hline & C5_P & 0.287 & & \\
\hline & C6_P & 0.273 & & \\
\hline & $\mathrm{C} 7 \_\mathrm{P}$ & 0.68 & & \\
\hline & C8_P & 0.84 & & \\
\hline & $\mathrm{C} 9 \_\mathrm{P}$ & 0.888 & & \\
\hline \multirow[t]{5}{*}{ Knowledge } & C3_K & 0.527 & 0.869 & 0.576 \\
\hline & C4_K & 0.694 & & \\
\hline & C5_K & 0.854 & & \\
\hline & C6_K & 0.82 & & \\
\hline & $\mathrm{C7}$ - K & 0.849 & & \\
\hline \multirow[t]{5}{*}{$\begin{array}{l}\text { Consumer Complaint } \\
\text { Behavior }\end{array}$} & D1 & 0.697 & 0.835 & 0.508 \\
\hline & D2 & 0.806 & & \\
\hline & D3 & 0.745 & & \\
\hline & D4 & 0.756 & & \\
\hline & D7 & 0.528 & & \\
\hline
\end{tabular}

$* *$ Item $1 \& 2$ of Knowledge were deleted

**Item 5 and 6 of Consumer Complaint behavior were deleted

\section{Discriminant Validity}

Next, the discriminant validity was applied in order to measure the degree to which items differentiate among constructs by examining the correlations between construct as in the model. To confirm there is no issue on discriminant validity, the items should load more strongly on their own construct and the AVE share between each construct and its measure should be greater than variance shared between the construct and another construct (Compeau, Higgins \& Huff, 1999). To test the discriminant validity, a Fornell and Larcker (1981) criterion have been conducted to compare the 
INTERNATIONAL JOURNAL OF ACADEMIC RESEARCH IN BUSINESS AND SOCIAL SCIENCES

Vol. 8, No. 11, Nov, 2018, E-ISSN: 2222-6990 (C) 2018 HRMARS

correlation between the construct and the AVE values. From the table 2, as presented in bolded values on diagonal were greater than the corresponding row and column values indicating the measure were discriminant.

However, the Fornell Larcker has been criticising due to some limitation as not reliable (Henseler, 2015). So that, the study replace with the analysis of Heterotrait-Monotrait ratio of correlations. Henseler (2015) mentioned the values of HTMT is greater than HTMT $_{0.85}$ which is 0.85 (Kline, 2011) or $\mathrm{HTMT}_{0.90}$ (Gold et al., 2001), then the result confirms there is an issue of discriminant validity. Thus from table 3, confirmed the constructs of this model was not have a discriminant validity issue.

Table 3: Fornell-Larcker Discriminant Analysis

\begin{tabular}{lcccc}
\hline Constructs & 1 & 2 & 3 & 4 \\
\hline 1. Attitude & $\mathbf{0 . 7 8 1}$ & & & \\
2. Consumer Complaint Behavior & 0.432 & $\mathbf{0 . 7 1 3}$ & & \\
3. Knowledge & 0.338 & 0.447 & $\mathbf{0 . 7 5 9}$ & \\
4. Personality & 0.778 & 0.37 & 0.337 & $\mathbf{0 . 7 1}$ \\
\hline
\end{tabular}

Table 4: Heterotrait-Monotrait Ratio (HTMT)

\begin{tabular}{lccc}
\hline Constructs & 1 & 2 & 3 \\
\hline Attitude & & & \\
Complaint Behaviour & 0.485 & & \\
Knowledge & 0.408 & 0.565 & \\
Personality & 0.850 & 0.414 & 0.393 \\
\hline
\end{tabular}




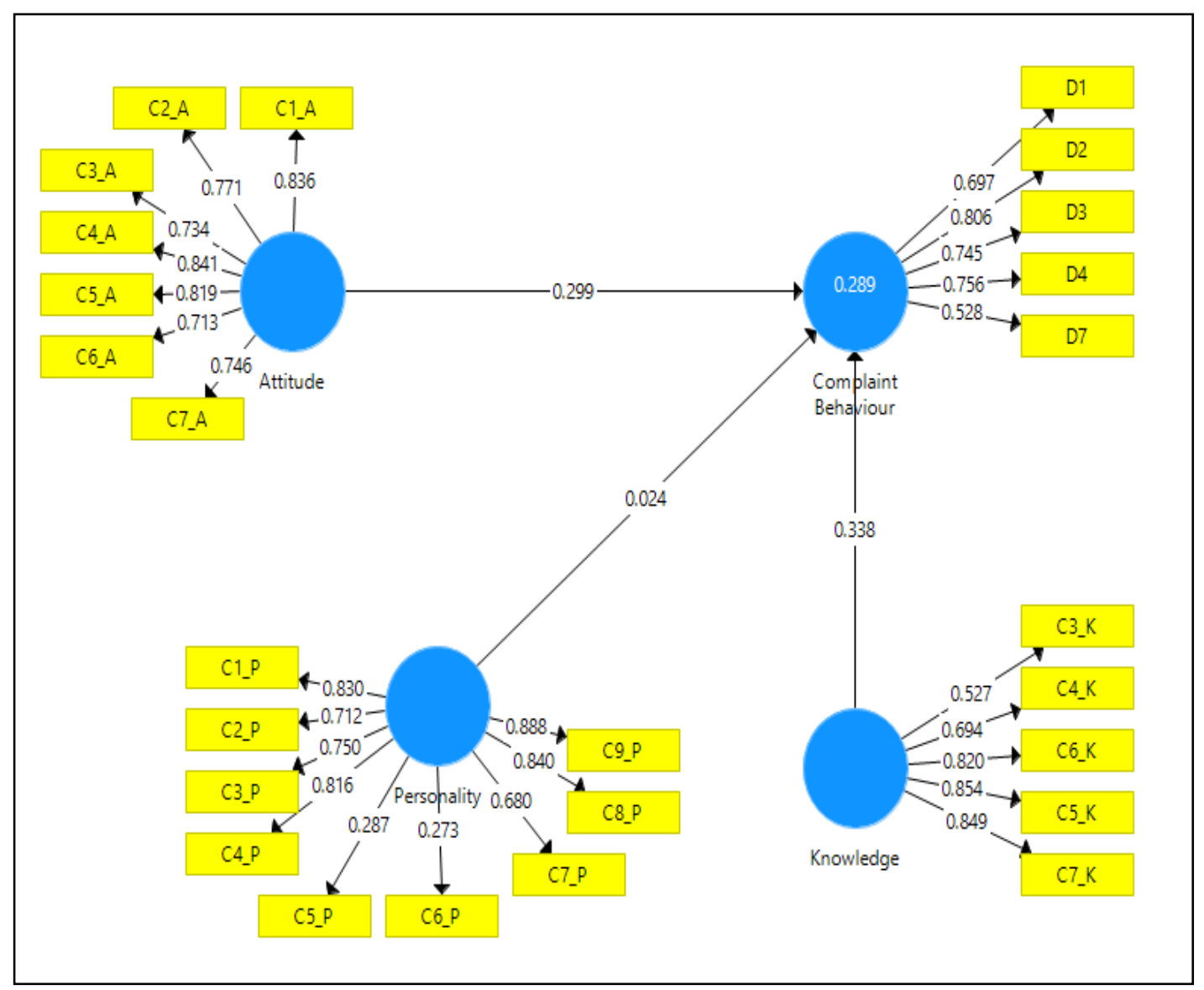

Figure 1: Measurement Model

\section{Structural Model}

In a structural model, the calculated values of $R$ square $\left(R^{2}\right)$, path loading ( $\beta$-Values) and the corresponding ( $t$-Values) by conducting a bootstrapping procedure with 500 samples. In further analysis, the prediction relevance and effects size of the relationship required assessing in structural model (Hair, Hult, Ringle and Sarstedt, 2014). From table 5, the R square $\left(R^{2}\right)$ of 28.9 percent of the variance in consumer complaint behavior was explained by attitude, knowledge, and personality.

Table 5 presented the finding of the structural model. The finding found that there were positive and statistically significant relationship between attitude $(\beta=0.299$, $t$-values $=3.547, p<0.01)$, knowledge $(\beta=0.338$, t-values $=6.41, p<0.01)$ and consumer complaint behaviour. The result confirmed the values of confidence interval corrected bias of lower limit $(L L=0.183)$ and upper limit $(U L=0.385)$ was not straddled on zero values. However, even there was a significant relationship but there was a small effect of the attitude $\left(f^{2}=0.049\right)$ and personality $\left(f^{2}=0.014\right)$ on complaining behaviour as recommended by Cohen (1988). Therefore the hypotheses of $\mathrm{H} 1$ and $\mathrm{H} 2$ was supported for this studied. In contrast, the finding of personality indicates there was a positive and not significant 
relationship with consumer complaint behaviour $(\beta=0.024$, $\mathrm{t}$-values $=0.273, p>0.01)$. The confidence interval corrected bias of lower limit (LL=-0.189) and upper limit $(U L=0.222)$ was straddled on zero values. Therefore the hypotheses $\mathrm{H} 3$ did not support for this study.

In further analysis, the assessment of predictive relevance $\left(Q^{2}\right)$ was conducted by using blindfolding procedures in PLS. According to Hair et al., (2014), the values of $Q^{2}$ is larger than 0 , the result can interpret that the exogenous constructs are predictive relevant to the endogenous constructs. The result revealed only knowledge $\left(Q^{2}=0.133\right)$ had sufficient predictive relevance to consumer complaint behaviour.

Table 5: Structural Model Analysis

\begin{tabular}{|l|c|c|c|c|c|c|c|c|}
\hline Constructs & $\begin{array}{c}\text { Standar } \\
\mathrm{d} \text { Beta }\end{array}$ & $\mathrm{SE}$ & $\begin{array}{c}\mathrm{T}- \\
\text { Value } \\
\mathrm{S}\end{array}$ & $\begin{array}{c}\mathrm{F} \\
\text { Squar } \\
\mathrm{e}\end{array}$ & $\mathrm{LL}$ & $\mathrm{UL}$ & $\begin{array}{c}\mathrm{R} \\
\text { Squar } \\
\mathrm{e}\end{array}$ & $\mathrm{Q}^{2}$ \\
\hline $\begin{array}{l}\text { Attitude -> Consumer } \\
\text { Complaint Behaviour }\end{array}$ & 0.299 & $\begin{array}{c}0.08 \\
4\end{array}$ & 3.547 & 0.049 & 0.120 & $\begin{array}{c}0.51 \\
4\end{array}$ & 0.183 & 0.133 \\
\hline $\begin{array}{l}\text { Knowledge -> } \\
\text { Consumer Complaint } \\
\text { Behaviour }\end{array}$ & 0.338 & $\begin{array}{c}0.05 \\
3\end{array}$ & 6.41 & 0.14 & 0.196 & $\begin{array}{c}0.46 \\
1\end{array}$ & \\
\hline $\begin{array}{l}\text { Personality -> } \\
\text { Consumer Complaint } \\
\text { Behaviour }\end{array}$ & 0.024 & $\begin{array}{c}0.08 \\
6\end{array}$ & 0.273 & 0.00 & - & $\begin{array}{c}0.22 \\
2\end{array}$ & \\
\hline
\end{tabular}

\section{DISCUSSION}

This study aimed to investigate the relationship between attitude, knowledge and personality and consumer complaint behaviour. The finding indicates only attitude and knowledge of the consumer statistically significant to consumer complaint behaviour. This fact revealed that, the more positive respondent's attitude towards complaining, the more complaint they will lodge. This result supported the previous studies conducted by Andreassen and Streukens, (2013), who found that attitude has direct positive antecedents of complaint behavior. In a similar finding with knowledge result, Zhoa and Md Nor Othman well explained that more knowledge of consumers have, the more likely they will engage in consumer complaint behaviour. The exception of personal result found was contrast with the previous studied by Berry, Tanford and Montgomery (2014), revealed that personality significantly mostly influence on consumer complaint behaviour.

The implication of this study highlight a consumer complaint behavior (CCB) is vital to the organization for several empirical reasons. Customer satisfaction or dissatisfaction ratings are good indicators of firm's performance to forecast future profit and return on investment. Firms that continuously and increasingly use customer satisfaction and dissatisfaction index as a criterion for analyzing service performance will create more loyal customer as well as will attract more potential customers. This is because; company's awareness of customer dissatisfaction is dependent upon consumers complaining to the store of if consumers take action to inform the organization about their dissatisfaction episode. 


\section{CONCLUSIONS}

As conclusion, consumers will lodge a complaint when they dissatisfied with the service offered because they are confident that company will rectify the issue. However, consumers also will retaliate on social media if they do not receive any response from the company with regards to their complaint. The shift of consumer's attitudes and knowledge about complain positively affect the consumer behavior, as a service provider should put an extra effort to attend consumer's complaint. They perceive that the company will help them to rectify the problem or service failure experienced by them. Companies should listen to the voice of customers, understand about their needs and fulfill their perceptions and expectations as well as foster a climate of continuous improvement based on the consumer's complaint experience. As in future study, may extends the dissatisfaction and consumer complaint behavior study in other service industries such as hospitality, retail or public transportation industry as very few research has been conducted in vary industries.

\section{ACKNOWLEDGEMENTS}

The authors gratefully acknowledge the help of the Institute of Research Management and Innovation, Universiti Teknologi MARA in providing the Lestari Grant (Project Number: $=600$ IRMI/Dana KCM 5/3/LESTARI (199/2017). The authors are also thankful to all respondents who have participated in this study.

\section{REFERENCES}

Alfansi, L. and Atmaja, F.T. (2011). Service failure and complaint behavior in the public hospital industry: The Indonesian experience. Journal of Non-Profit and Public Sector Marketing. 21: 309325.

Andreassen, T. W., \& Streukens, S. (2013). Online complaining. Managing Service Quality, 23(1), 424. https://doi.org/http://dx.doi.org/10.1108/09604521311287632

Berry, R., Tanford, S., \& Montgomery Alison Green, R. (2014). How we Complain: The effect of personality on Consumer Complaint Channels. Journal of Hospitality \& Tourism Research Month, XX(X), 1-28. https://doi.org/10.1177/1096348014550921

Broadbridge, A., \& Marshall, J. (1995). Consumer Complaint Behavior: The Case of Electrical Goods.

Christina, Zhang, B., Anbound, A., and Cihan, C. (2017). Generation Y's positive and negative eWOM: Use of social media and mobile technology. International Journal of Contemporary Hospitality Management. 29(2).

Clark, J. (2013). Conceptualizing Social Media as Complaint Channel. Journal of Promotional Communications, 1(1), 104-124.

Cohen, J. (1992). A power primer. Psychological Bulletin, 112(1), 155-159. http://dx.doi.org/10.1037/0033-2909.112.1.155

Deborah Compeau, Christopher A. Higgins \& Sid Huff. (1999). Social Cognitive Theory and Individual Reactions to Computing Technology: A Longitudinal Study. MIS Quarterly Vol. 23, No. 2 (Jun., 1999), pp. $145-158$

Ekiz, H.E. and Au.N. (2009). Issues and opportunities of internet hotel marketing in developing country. Journal of Travel, Tourism Marketing (SSCI Journal). 26(3): 225-2243. 
INTERNATIONAL JOURNAL OF ACADEMIC RESEARCH IN BUSINESS AND SOCIAL SCIENCES

Vol. 8, No. 11, Nov, 2018, E-ISSN: 2222-6990 @ 2018 HRMARS

Fornell, C. G., \& Larcker, D. F. (1981). Evaluating structural equation models with unobservable variables and measurement error. Journal of Marketing Research, 18(1), 39-50

Gold, A. H., Malhotra, A., \& Segars, A. H. (2001). Knowledge management: an organizational capabilities perspective. Journal of Management Information Systems, 18(1), 185-214.

Hair, J.F, Black, W.C, Babin B.J.,(2010). Multivariate data analysis: A global perspective, New Jersey, Pearson Prentice Hall,).

Hair, J.F., Hult, G. T.M., Ringle, C.M., \& Sarstedt, M., (2014). A primer on partial least square Structural Equation Modelling (PLS-SEM). Los Angeles, SAGE Publication.

Henseler, J., Ringle, C.M., Sarstedt, M., (2015). A new criterion for assessing discriminant validity in variance-based structural equation modeling, Journal of Academy Mark Sciences, 43:115135.

Huang, J. H., Huang, C. T., \& Wu, S. (1996). National character and response to unsatisfactory hotel service. International Journal of Hospitality Management, 15(3), 229-243.

Hunt, H.K. (1977). Conceptualization and Measurement of Consumer Satisfaction and Dissatisfaction. Boston:

Marketing Science Institute, Harvard University.

Kaynak, E., Kucukemiroglu, O. and Odabasi, Y. (1992). ConsumerComplaint Handling in An Advanced Developing Country: AnE mpirical Investigation. Journal of Business Ethics. 11(11):813.

Keng, K.A., Richmond, D. and Han, S. (1995). Determinants of Consumer Complaint Behavior: A study of Singapore Consumers. Journal of International Consumer Marketing, 8(2):59.

Kline, R. B. (2011). Principles and practice of structural equation modeling. New York: Guilford Press.

Mat, A., Said, A. M., Bakar, E. A., Kori, N. L., \& Munir, Z. A. (2016). Determining the Income Differences and Complaint Behavior among Automobile Repairs and Service Consumers in Shah Alam, Malaysia. Procedia Economics and Finance, 37(16), 21-26. https://doi.org/10.1016/S2212-5671.

Phau, I. and Sari P.R. (2004). Engaging in Complaint Behavior: An Indonesian Perspective. Marketing Intelligence and Planning. 22(4): 407-426

Zhao, W. and MdNor Othman. (2010). The influence of knowledge of consumer protection and perception of marketing factors on consumer complaint behavior: A study of Malaysia consumers. OIDA International Journal of Sustainable Development. 1(9): 27-35. 